\title{
A (AUTO)NARRATIVA DE VIDA NA CONSTRUÇÃO DA CANÇÃO POLIFÔNICA "QUEM É ESSA AGORA/PRA RUA ME LEVAR”, DE MARIA BETHÂNIA
}

\author{
RAFAEL BATISTA ANDRADE ${ }^{1}$
}

\author{
Programa de Pós-Graduação em Estudos Linguísticos - FALE-UFMG \\ Instituto Federal de Minas Gerais (Campus Congonhas) - Dep. Linguagens e Códigos \\ Av. Michael Pereira de Souza, 3007 - 36415-000 \\ Campinho, Congonhas-MG - Brasil \\ rafael.andradedifmg.edu.br
}

\begin{abstract}
Resumo. Neste trabalho, analisamos a hibridização de um trecho do livro $O$ rio do meio com a canção "Pra rua me levar". Retomando a noção de canção-poema, objetivamos mostrar a possível emergência do gênero canção polifônica na interpretação de Maria Bethânia. Formam parte do quadro teórico-metodológico os modos de organização do discurso e os estudos sobre narrativa de vida. As análises revelam uma mobilização particular de estratégias descritivas e narrativas, instauradas no discurso, atribuídas ao enunciador da canção polifônica que ressignifica representações e opiniões de outros enunciadores, reforçando a hipótese dessa hibridização ser um possível gênero emergente.
\end{abstract}

Palavras-chave: descrição; hibridização; narrativa; polifonia; canção.

\begin{abstract}
The analysis is carried out upon the hybridization of an excerpt from the book $O$ rio do meio with the song "Pra rua me levar". Retrieving the notion of poem-song, we aimed to show the possible emergence of the polyphonic song genre in Maria Bethania's interpretation. The theoretical and methodological framework consists of means of speech organization and studies on life narrative. The analysis revealed specific mobilization of descriptive and narrative strategies introduced in the discourse attributed to the enunciator of the polyphonic song that reframes representations and opinions of other enunciators, reinforcing the hypothesis that this hybridization may correspond to an emerging genre.
\end{abstract}

Keywords: description; hybridization; narrative; polyphony; song.

\section{Introdução}

O atual estágio das investigações sobre a hibridização entre canção e poema realizada pela intérprete Maria Bethânia sugere ainda uma abordagem com expectativas significativas dentro do campo dos Estudos Linguísticos, uma vez que tal pesquisa pode ampliar o estudo sobre os gêneros emergentes, iniciada, no Brasil, por Marcuschi (2008,

\footnotetext{
${ }^{1}$ Doutorando em Estudos Linguísticos no Programa de Pós-Graduação em Estudos Linguísticos - FALEUFMG. Professor no Instituto Federal de Minas Gerais (Campus Congonhas).
} 
p. 198-206), autor que se dedicou, especialmente, aos gêneros oriundos do ambiente virtual.

Em trabalho anterior (ANDRADE, 2015), mostramos, por meio da análise de sete canções e sete poemas unidos num mesmo espaço discursivo, as canções-poemas como fruto da enunciação da intérprete Maria Bethânia e evidenciamos que essa hibridização pode ser caracterizada como um novo texto. Além disso, essas investigações também apontaram para a hipótese de que a canção-poema poderia ser classificada como um gênero emergente no/do domínio literário.

Neste artigo, damos sequência ao referido estudo, objetivando, porém, analisar a hibridização realizada pela cantora (intérprete) $)^{2}$ Maria Bethânia na canção "Pra rua me levar", de Ana Carolina e Totonho Villeroy, com um trecho do livro O rio do meio, de Lya Luft. Esperamos mostrar que algumas estratégias discursivas da cantora/intérprete Maria Bethânia podem nos permitir visualizar o gênero discursivo canção polifônica enquanto um possível gênero de discurso emergente. Para isso, dividimos o presente trabalho em três seções. Na primeira, tratamos dos aspectos metodológicos e teóricos. $\mathrm{Na}$ segunda, apresentamos a análise dos textos que constituem o corpus do presente trabalho, e, por fim, expomos as conclusões dessa investigação, aliando os resultados obtidos aqui com aqueles que já vinham sendo revelados em outros trabalhos.

\section{Metodologia e aspectos teóricos}

A seleção dos textos que analisamos neste artigo resulta de um mapeamento que vimos fazendo ao longo da pesquisa em torno das hibridizações realizadas pela intérprete Maria Bethânia. Assim, julgamos necessária a contextualização resumida dessas investigações para mostrarmos que o presente trabalho tem um respaldo em investigações mais abrangentes cujos desdobramentos ainda apontam para novas perspectivas de análise.

\subsection{Da canção-poema à canção polifônica de Maria Bethânia}

Em Andrade (2015), restringimos as análises apenas àquelas hibridizações realizadas por Maria Bethânia entre canção e poema por razões metodológicas. Tais análises nos permitiram lançar a hipótese de que a cantora/intérprete deveria ser vista como um terceiro enunciador: o da canção-poema, fato que nos permitiu caracterizar essa hibridização como um novo texto no qual teríamos a projeção de uma intérprete com dimensões autorais. Nesse trabalho, compreendemos o enunciador como sinônimo de

\footnotetext{
${ }^{2}$ De acordo com Houaiss e Villar (2009, p. 1099), intérprete é "aquele que toca ou canta uma peça musical". Vemos, assim, que o termo cantor é mais restrito que o primeiro. Ressaltamos ainda que, em alguns dicionários especializados, não encontramos o termo intérprete, mas apenas interpretação. Nesse sentido, tanto Dourado (2004, p. 169) quanto Kennedy (1994, p. 350) salientam que, na interpretação, há implicações emotivas e julgamentos da personalidade do intérprete que ultrapassam as indicações mais formais (a partitura, por exemplo) de como uma música deve ser tocada ou cantada. Sabino (2010, p. 19), inclusive, lembra que Maria Bethânia prefere ser chamada de intérprete. No entanto, tomaremos esses dois termos como equivalentes, porque não é nosso objetivo analisar a "performance" de Maria Bethânia: presença no palco, timbre de voz, mudanças melódicas e harmônicas etc.
} 
autor implícito, situado na instância da enunciação, que se constitui como fonte de valores. Trata-se de uma releitura do conceito de destinador implícito da enunciação (ou da "comunicação") elaborado por Greimas e Courtés (2011). Ressaltamos a importância do termo implícito, já que é essa característica que distingue o enunciador do narrador. Este "é um actante obtido pelo procedimento de debreagem, e instalado explicitamente no discurso" (GREIMAS; COURTÉS, 2011, p. 171).

Em síntese, a nossa abordagem baseou-se na articulação entre elementos teóricometodológicos da Semiótica Francesa e a noção de éthos discursivo (MAINGUENEAU, 2008; CRUZ, 2009). A partir da tese de que a seleção de temas e figuras revelam a ideologia, os valores da instância da enunciação, analisamos o éthos de Maria Bethânia. Assim, a análise dos temas e figuras das sete canções-poemas selecionadas possibilitaram a visualização das diferenças "de visão de mundo" dos enunciadores dos poemas, das canções e das canções-poemas.

A título de exemplo, reproduzimos a seguir uma síntese da análise da cançãopoema O poeta come amendoim / Canto do Pajé. Nela se pode perceber claramente que cada enunciador possui uma "visão de mundo particular" e que se trata de enunciadores diferentes. Ou seja, podemos visualizar os valores e as ideologias enquanto marcas enunciativas dos autores implícitos, respectivamente, no poema, na canção e na hibridização realizada por Maria Bethânia entre a canção e o poema. Trata-se, portanto, de algumas possibilidades de leitura que poderão ser resgatadas pelos enunciatários (destinatários implícitos) enquanto sujeitos produtores de sentido.

Quadro 1. Síntese da hibridização entre a canção Canto do Pajé e o poema 0 poeta come amendoim.

\begin{tabular}{|c|c|c|c|}
\hline $\begin{array}{l}\text { Canção- } \\
\text { poema }\end{array}$ & $\begin{array}{c}\text { Enunciador do } \\
\text { poema }\end{array}$ & Enunciador da canção & Enunciador da canção-poema \\
\hline $\begin{array}{l}\text { poeta } \\
\text { come } \\
\text { amendoim / } \\
\text { Canto do } \\
\text { Pajé }\end{array}$ & $\begin{array}{l}\text { Reconstrução do } \\
\text { conceito de } \\
\text { patriotismo: deve-se } \\
\text { amar a pátria por ser } \\
\text { o que é. }\end{array}$ & $\begin{array}{lr}\text { Desativação da } & \text { figura do } \\
\text { índio como } & \text { símbolo } \\
\text { nacional; } & \text { formação } \\
\text { ideológica do } & \text { direito } \\
\text { inalienável do índio à } \\
\text { terra. }\end{array}$ & $\begin{array}{l}\text { Enfase no tema da mestiçagem, } \\
\text { com o surgimento da formação } \\
\text { ideológica que reconhece a } \\
\text { necessidade de o Estado assegurar } \\
\text { a todos os cidadãos brasileiros, } \\
\text { indistintamente, o acesso à terra. }\end{array}$ \\
\hline
\end{tabular}

A partir desse exemplo, podemos também esclarecer o uso do termo hibridização em nosso trabalho. Trata-se da articulação (ou junção) de dois gêneros de discurso distintos, a canção e o poema, num mesmo espaço textual. Dela surge, necessariamente, um novo contrato regido pelo enunciador da canção-poema com novos efeitos de sentido, o que evidencia a formação de um terceiro texto. No caso apresentado, a visualização dos temas da mestiçagem e do acesso à terra a todos os cidadãos brasileiros demonstra o surgimento desse contrato cuja instância enunciativa é o enunciador da canção-poema. Isso porque esses valores são perceptivos apenas sob o prisma desse sujeito.

Além disso, esse terceiro texto é dotado de estilo e construção composicional próprios. No primeiro caso, verificamos a presença de um estilo autoral que ultrapassa a exploração de recursos de técnica vocal, comum no caso de intérpretes/cantores da MPB, consolidando-se com a releitura das letras das canções entrelaçadas a poemas. No segundo caso, há uma organização textual vista sob um ponto de vista incipiente, em que os leitores/ouvintes, assumindo o papel de destinatários implícitos, são convidados a 
supor (e fazer) as transições que se impõem entre os elementos postos em presença do outro, incluindo a compreensão da reorganização do discurso: seu início, meio e fim. Como o estilo verbal e a construção composicional formam, junto com o conteúdo temático, a tríade que caracteriza os diferentes gêneros de discurso no entender de Bakhtin (2003), lançamos a hipótese de que a canção-poema poderia ser vista como um "novo" gênero de discurso.

Entretanto, já vínhamos ressaltando que encontramos, na análise da discografia de Maria Bethânia, hibridização de canções com trechos retirados de textos de outras obras dentro do domínio literário: peça de teatro (dramaturgia), conto, romance, memórias e novela. Assim, elaboramos agora os seguintes quadros que contêm uma seleção de parte significativa das hibridizações realizadas pela cantora/intérprete, com o intuito de expor um corpus que ainda carece de análise e que pode revelar muitos aspectos relevantes para a área de Letras e para trabalhos interdisciplinares.

Quadro 2. Hibridizações realizadas por Maria Bethânia entre canções e trechos de outros gêneros literários retiradas de CDs de estúdio.

\begin{tabular}{|l||c||l||l||}
\hline \multicolumn{1}{|c||}{ Nome do disco } & Ano & \multicolumn{1}{|c||}{ Gênero mobilizado } & \multicolumn{1}{|c||}{ Hibridizaçóes } \\
\hline \hline Pássaro da Manhã & 1977 & $\begin{array}{l}\text { Novela/Romance A }- \text { A } \\
\text { hora da estrela - } \\
\text { Clarice Lispector }\end{array}$ & Texto de Clarice Lispector/ O que será? \\
\hline \hline $\begin{array}{l}\text { Maria Bethânia } \\
\text { Brasileirinho }\end{array}$ & 2003 & $\begin{array}{l}\text { Conto - "Barra da vaca" } \\
\text { - Guimarães Rosa3 }\end{array}$ & Cigarro de paia/texto de Guimarães Rosa \\
\hline \hline Que falta você me faz & 2005 & $\begin{array}{l}\text { Teatro (Dramaturgia) - } \\
\text { "Orfeu negro" } \\
\text { Vinícius de Moraes }\end{array}$ & Lamento no morro/Monólogo de Orfeu \\
\hline \hline Maria Bethânia Pirata & 2006 & $\begin{array}{l}\text { Romance - Grande } \\
\text { sertão: Veredas - } \\
\text { Guimarães Rosa }\end{array}$ & $\begin{array}{l}\text { Pensar na pessoa que se ama/ Eu que não } \\
\text { sei quase nada do mar }\end{array}$ \\
\hline \hline
\end{tabular}

Quadro 3. Hibridizações realizadas por Maria Bethânia entre canções e trechos de outros gêneros literários retiradas de CDs ao vivo.

\begin{tabular}{||l||l||l||l||}
\hline Nome do disco & Ano & Gênero mobilizado & Hibridizações \\
\hline \hline Rosa dos ventos & 1971 & $\begin{array}{l}\text { Romance - Água viva - } \\
\text { Clarice Lispector }\end{array}$ & Texto N 5/Movimento dos Barcos \\
\hline \hline Imitação da vida & 1997 & $\begin{array}{l}\text { Prosa }{ }^{4}-\text { Livro do } \\
\text { Desassossego - Fernando } \\
\text { Pessoa }\end{array}$ & Eu agi sempre/Terezinha \\
\hline \hline Maricotinha ao vivo & 2002 & $\begin{array}{l}\text { Memórias/autobiografia ou } \\
\text { ensaios mais leves - "O rio } \\
\text { do meio “- Lya Luft }\end{array}$ & Quem é essa agora/Pra rua me levar \\
\hline Dentro do mar tem rio & 2007 & $\begin{array}{l}\text { Novela - Noites do sertão - } \\
\text { Guimarães Rosa }\end{array}$ & $\begin{array}{l}\text { Amor é sede depois de se ter bem } \\
\text { bebido/A saudade mata a gente }\end{array}$ \\
\hline \hline
\end{tabular}

\footnotetext{
${ }^{3}$ Essa hibridização foi a única dos dois quadros que já foi analisada anteriormente. Em Andrade (2012), propusemos analisá-la com base no conceito de polifonia e a partir do quadro teórico-metodológico do Modelo Modular de Análise do Discurso. Entretanto, julgamos relevante inseri-la no presente quadro para mostrar a diversidade dos gêneros literários mobilizados por Maria Bethânia.

${ }^{4}$ Estamos usando o termo "prosa" apenas para mostrar que essa obra possui uma classificação diferente de poema e de outros gêneros presentes nesse quadro, mas a sua classificação dependerá de uma investigação sobre a literatura especializada.
} 
Ressaltamos, porém, o fato de termos elaborado dois quadros, e não apenas um. Ao separar as hibridizações retiradas de CDs de estúdio daquelas encontradas em CDs ao vivo, quisemos pôr em evidência que esse fenômeno ocorre em diferentes situações. Assim, pretendemos mostrar que tal processo de hibridização ultrapassa a questão da performance, que não se constitui como objeto de pesquisa neste artigo por razões teóricometodológicas.

A partir desses quadros, selecionamos o caso da hibridização entre uma canção e um trecho do gênero literário memórias/autobiografia para demonstrar que o caráter fundamental de criação de um novo texto a partir da mobilização de sentidos outros é o eixo fundamental dessa técnica de hibridização, a qual podemos denominar, em sentido amplo, de canção polifônica de Maria Bethânia. Assim, objetivamos mostrar os efeitos de sentido gerados pela atuação do enunciador da canção polifônica que se diferencia dos planos de leitura originados nos contratos do enunciador da canção e do enunciador da autobiografia selecionada. A análise que realizaremos será tomada como exemplo do que pode ocorrer em cada hibridização presente nesses dois quadros. Ressaltamos, entretanto, que essa hipótese já encontra respaldo nas análises das canções-poemas. Isso porque o caráter fundamental da hibridização de gerar novos efeitos de sentido se mantém tanto na canção-poema como na canção polifônica.

Basicamente, lançamos a hipótese de que as canções $O$ que será?, Cigarro de paia, Lamento no morro, Eu que não sei quase nada do mar, Movimento dos barcos, Terezinha, Pra rua me levar, A saudade mata a gente podem ser interpretadas conforme as posições do enunciador de cada uma dessas canções. Não obstante, quando ocorre a hibridização dessas canções com os respectivos trechos de obras de diferentes gêneros literários, há uma reorganização discursiva, o surgimento de um novo texto com outras possibilidades de leituras. Estas devem ser vistas sob a ótica do enunciador da canção polifônica cuja estratégia de releitura desloca trechos de obras literárias para ressignificar o conteúdo verbal da canção interpretada. Portanto, essas citações deixam de ser interpretadas no quadro enunciativo de cada uma dessas obras e passam a ser lidas como parte da canção polifônica.

Com isso, pretendemos sugerir um avanço em relação à hipótese de caracterizar esse texto resultante desse mecanismo de hibridização realizado pela intérprete Maria Bethânia ao empregar termos que indicaram o surgimento de um novo gênero no campo literário. Trata-se dos estudos de Bakhtin (2010), que revelaram um novo gênero: o romance polifônico de Dostoievski, em que a carnavalização da literatura teve um papel fundamental, assegurando a tese do autor e, ao que tudo indica, também poderá orientar a tese da canção polifônica. Nessa orientação, levamos em conta não apenas a presente análise, mas também os trabalhos anteriores sobre a canção-poema. Esta, na realidade, passará a ser vista agora como um subgênero da canção polifônica, uma vez que a diferença entre esses termos reside na abrangência do segundo que abarcará todas as hibridizações realizadas pela intérprete Maria Bethânia entre canções e vários gêneros literários: poema, memórias, peça de teatro (dramaturgia), conto, romance e novela.

Além disso, ressaltamos a relevância de adotarmos neste trabalho outra perspectiva teórico-metodológica diferente daquela que adotamos em trabalhos anteriores. Em Lara e Andrade (2013), utilizamos as categorias da Semiótica Francesa. Também denominada de Semiótica do Discurso; teoria que teve sua origem na França 
dos anos 1960 por meio de pesquisas do Grupo de Investigações Semiolinguísticas da Escola de Altos Estudos em Ciências Sociais - Paris. Seu principal mentor foi o lituano, radicado na França, Algirdas Julien Greimas, razão pela qual é também denominada Semiótica Greimasiana. No entanto, essa teoria vem recebendo, desde sua origem, diversas contribuições de outros autores a partir do desenvolvimento de variadas metodologias.

No trabalho em questão, partimos da proposta de divisão entre o plano do conteúdo e o plano da expressão. O primeiro pode ser apreendido por meio do percurso gerativo de sentido, que simula a geração do sentido em três níveis: o nível fundamental, o nível narrativo e o nível discursivo, sendo que "todos eles têm uma sintaxe, que é uma maneira de organizar os conteúdos, e uma semântica, que são os investimentos de sentidos estruturados pela sintaxe" (FIORIN, 2008, p. 12). As análises do corpus foram realizadas a partir desses três níveis do percurso gerativo de sentido e articuladas com a noção de gênero de discurso de Bakthin (2003). Já em Andrade (2015), a perspectiva teórica adotada foi uma articulação entre elementos do nível discursivo da Semiótica Francesa temas, figuras e isotopias - e as categorias de éthos discursivo (MAINGUENEAU, 2008; CRUZ, 2009), estilo (FIORIN, 2008b), autoralidade (MAINGUENEAU, 2010) e gêneros de discurso (BAKHTIN, 2003; MAINGUENEAU, 2010; 2004).

\subsection{Quadro teórico-metodológico: narrativa de vida e semiolinguística}

O primeiro fato a ser abordado aqui é a mudança de foco no nosso próprio corpus. Em trabalhos anteriores, priorizávamos a hibridização entre os gêneros canção e poema. Isso porque, de fato, a ocorrência de mobilização do gênero poema é quantitativamente superior em relação a outros, o que deu consistência à formação do corpus, principalmente na pesquisa de Andrade (2015). Agora damos lugar a hibridização da canção com outros gêneros literários, tomando como exemplo a mobilização de um trecho de autobiografia. Razão pela qual o termo canção-poema dará lugar ao termo canção polifônica, já que o primeiro não pode abarcar adequadamente a hibridização com a autobiografia, tampouco com os outros gêneros literários descritos nos quadros da seção anterior.

Além disso, também mobilizamos, no caso do presente artigo, categorias teóricometodológicas diferentes, o que certamente enriquecerá as nossas hipóteses de trabalho. Isso porque também pretendemos demonstrar que tais fatos podem ser verificados a partir de diferentes ângulos teóricos. Por isso, passamos a expor as categorias que formam o quadro teórico-metodológico para as posteriores análises.

Para descrevermos as estratégias linguístico-discursivas que viabilizam o processo de significação da canção polifônica, utilizamos algumas categorias teóricas advindas dos estudos de Machado (2014), Bakhtin (2010) e Charaudeau (2012). Começamos essa exposição teórica lembrando que, muitas vezes, é o próprio corpus que acaba direcionando, ou mesmo exigindo, a mobilização de certas teorias e determinados procedimentos metodológicos. Ao verificarmos o próprio impasse de classificação para o livro $O$ rio do meio, de Lya Luft - trata-se de um livro de memórias/autobiografias, mas 
a própria autora o classifica como "ensaios mais leves" - verificamos a necessidade de analisarmos o trecho retirado desse livro sob uma perspectiva teórica da narrativa de vida.

Machado $(2015,2014)$ considera a narrativa de vida ${ }^{5}$ como um macro ato de linguagem que visa estabelecer uma forma de comunicação com algum interlocutor. Esse mecanismo discursivo pode ser visto, então, ainda segundo a autora, como um fator de construção de identidades e como uma prática narrativa de alguém que se conta mesmo se este não for o propósito deste ou daquele gênero. Fato relevante para os textos que analisamos, pois acreditamos que a narrativa de vida pode estar presente também em canções, ainda que essa prática não seja o seu principal propósito. Assim, para as análises que empreendemos, acreditamos que esse macro ato de linguagem funciona como a linha discursiva que costura os dois textos (canção e trecho da autobiografia), gerando a canção polifônica, já que as narrativas contam histórias, mas fazem mais que isso: elas detêm uma maneira de persuasão.

Acreditamos, portanto, que essa linha discursiva resumiria parte significativa das estratégias discursivas utilizadas pela cantora/intérprete Maria Bethânia. Antes de descrevermos algumas dessas estratégias que serão utilizadas para a análise do corpus, ressaltamos a importância dessa união de textos/vozes, pois, como já havíamos adiantado na seção precedente, o termo canção polifônica é uma referência ao "romance polifônico" e se justifica por este comportamento da variedade de vozes que julgamos ser perfeitamente transposto para a estratégia de hibridização realizada pela cantora/intérprete, já que os personagens podem ser vistos, dentro de uma perspectiva dos Estudos Linguísticos, como uma instância discursiva específica dentro de um determinado gênero discursivo:

encontrar sua voz e orientá-la entre outras vozes, combiná-la com umas, contrapô-la a outras ou separar a sua voz da outra à qual se funde imperceptivelmente são as tarefas a serem resolvidas pelas personagens no decorrer do romance. (BAKHTIN, 2010, p. 277)

Assim, no decorrer das análises, também recorremos à teoria polifônica de Bakhtin, procurando demonstrar as similitudes entre o processo de hibridização realizado por Maria Bethânia e alguns fatos que caracterizaram o romance polifônico de Dostoievski, segundo Bakthin (2010). Ao depararmo-nos com a canção polifônica, necessitamos encontrar a voz do enunciador que proporciona novos efeitos de sentido através da junção da canção com o trecho da obra literária analisada. Isso significa verificar como o enunciador da canção polifônica combina, contrapõe ou separa em sua voz os efeitos de sentido atribuídos ao enunciador da canção e ao enunciador do livro $O$ rio do meio, gerando um terceiro texto.

Passemos agora à exposição das categorias teórico-metodológicas que utilizamos na análise do corpus. Trata-se, em linhas gerais, de alguns conceitos advindos da Teoria Semiolinguística. De acordo com Machado (2008), essa teoria é uma vertente da Teoria do Discurso de linha Francesa. Ela é resultado da tese de doutorado de Patrick Charaudeau, defendida em 1979, sob a orientação de Bernard Poitiers. Desde então, o autor vem reformulando a sua teoria, como percebemos em Charaudeau (1992; 2012). A

\footnotetext{
${ }^{5}$ Algumas vezes, optamos por utilizar o termo (auto)narrativa de vida para evidenciar esse macro ato de linguagem enquanto produto de um narrador que fala de si próprio.
} 
Semiolinguística parte do pressuposto de que o sentido é resultante de operações discursivas de sujeitos do discurso, a partir de uma situação bem determinada e regulada por um contrato enunciativo. Em linhas gerais, a teoria pode ser dividida em dois procedimentos analítico-enunciativos. No primeiro, denominado enunciação ampliada, levam-se em conta a descrição da dinâmica das interações sociais protagonizadas por atores portadores da identidade social e discursiva e as circunstâncias de produção do ato comunicativo. Já na segunda etapa, os procedimentos linguísticos são analisados enquanto marcas sinalizadoras da legitimidade do eu comunicante.

Ademais, Machado acrescenta que o ato de comunicação possui três componentes. O primeiro deles é a situação de comunicação. Os modos de organização do discurso (modo enunciativo, descritivo, narrativo e argumentativo) constituem o segundo componente. Por último, tem-se a função de base, ou seja, a finalidade discursiva do projeto de fala do locutor. Para a análise do corpus, focamos algumas categorias dos modos de organização do discurso (CHARAUDEAU, 2012) que consideramos as mais produtivas para os objetivos propostos neste artigo. Trata-se do modo de organização descritivo e do modo de organização narrativo (CHARADEAU, 2012, p. 107-200). Antes, contudo, esclarecemos o conceito de enunciador dentro desse quadro teórico.

Em Semiolinguística, entende-se por enunciador ou sujeito enunciante aquele que se encontra inscrito no espaço interno do discurso e faz par com o sujeito destinatário. Assim, ele não se confunde com o sujeito de comunicação, que se encontra no espaço externo da comunicação e, em síntese, é a pessoa responsável socialmente por determinada enunciação. Em outras palavras, os valores e ideologias que analisamos em um texto são percebidas no plano do enunciador, não no plano do sujeito de comunicação. Percebe-se, por conseguinte, que esse conceito é condizente com a noção adotada por nós em trabalhos anteriores, como mostramos no início deste artigo, apesar, é claro, das diferenças terminológicas e dos objetivos de cada teoria.

Uma vez compreendida a diferença entre plano externo e interno, cabe ainda esclarecer as projeções assumidas pelo enunciador no plano interno. Por essa razão, não se confunde, por exemplo, enunciador, narrador e contador. O primeiro, como vimos, refere-se à instância enunciativa. Trata-se de um sujeito implícito. O segundo está relacionado com as marcas de subjetividade enunciativa. Isso quer dizer que tais marcas são remetidas ao mundo narrativo. Aliás, é por isso que podemos distinguir, em um texto, narrador de narradora, como veremos nas análises apresentadas na próxima seção. $\mathrm{O}$ terceiro é uma categoria utilizada para marcar o modo de organização do discurso enquanto projeção do enunciador. Para aqueles enunciados em que identificamos estratégias específicas do modo de organização "narrativo", utilizamos o termo contador.

Em síntese, em nossas análises, nos referiremos ao enunciador da canção, ao enunciador de $O$ rio do meio e ao enunciador da canção polifônica para evidenciar os valores, os efeitos de sentido em cada um desses textos. Nesse caso, trata-se de sujeitos implícitos. Não obstante, muitos desses significados encontram-se projetados nos enunciados atribuídos aos narradores de cada um desses textos através de diferentes estratégias como as de descrever e narrar. Razão pela qual utilizaremos o termo narrador para nos referirmos ao "eu" explícito de cada texto, resgatando inclusive a questão de gênero (narrador, narradora) e contador para marcar as estratégias próprias do modo de organização do discurso narrativo. 
Vejamos agora as categorias que utilizaremos na próxima seção para a análise do corpus. De acordo com o pesquisador francês, "descrever consiste em ver o mundo com 'um olhar parado' que faz existir os seres ao nomeá-los, localizá-los e atribuir-lhes qualidades que os singularizam" (CHARAUDEAU, 2012, p. 111, grifos do autor). Assim, parte das análises destina-se a evidenciar como essas estratégias de nomear, localizar e qualificar são (re)construídas no trecho de $O$ rio do meio, na canção "Pra rua me levar" e na canção polifônica (hibridização dos dois primeiros textos). Outro fator relevante para a análise do corpus está na própria relação desse modo de organização descritivo com os outros modos de organização do discurso. É justamente isso que o autor ressalta no referido trecho e que norteia outra parte significativa de nossa análise, reforçando, inclusive, o caráter de fio condutor que a (auto)narrativa de vida tem na re(construção) do terceiro texto, a canção polifônica de Maria Bethânia.

Toda descrição está sempre em relação com outros modos de organização do discurso (Narrativo, Argumentativo), e que, sem ser totalmente dependente, ela adquire sentido (ou uma parte de seu sentido) em função destes outros modos. (CHARAUDEAU, 2012, p. 117 , grifos do autor)

No caso dos textos analisados, essa relação é estabelecida com o modo narrativo, razão pela qual passamos a focá-lo agora. O narrativo, ao contrário do modo descritivo, "leva-nos a descobrir um mundo que é construído no desenrolar de uma sucessão de ações que se influenciam umas às outras e se transformam num encadeamento progressivo" (CHARAUDEAU, 2012, p. 157). Nossa tarefa, então, na seção subsequente, é colocar em evidência qual o mundo que está sendo descoberto a partir da construção do desenrolar de uma sucessão de ações no trecho de $O$ rio do meio, na canção "Pra rua me levar" e na canção polifônica.

Para isso, partimos do pressuposto de que podemos encontrar uma projeção específica, conforme cada uma das instâncias enunciativas presente em cada um dos textos analisados, sendo que tais projeções podem nos permitir identificar um contador. Este termo, portanto, não se confunde com o enunciador, nem com a instância enunciativa, pois se trata de uma de suas projeções. Isso porque pode-se atribuir ao enunciador diversas estratégias. Quando estas são especificamente relacionadas ao modo narrativo, utilizamos essa categoria proposta por Charaudeau. Acreditamos que, no discurso atribuído a ele, possamos a encontrar vários investimentos de uma intencionalidade direcionada a um destinatário específico de cada texto segundo construções particulares de sentidos. Por isso, assumimos junto com Charaudeau que, para a existência da narrativa, deve haver

um "contador" (que se poderá chamar de narrador, escritor, testemunha, etc.), investido de uma intencionalidade, isto é, de querer transmitir alguma coisa (uma certa representação da experiência do mundo) a alguém, um "destinatário" (que se poderá chamar de leitor, ouvinte, espectador, etc.), e isso, de certa maneira, reunindo tudo aquilo que dará um sentido particular a sua narrativa. Evidentemente, não estão excluídas dessa intencionalidade todas as significações não conscientes das quais o contador poderia ser o portador involuntário. (CHARAUDEAU, 2012, p. 53) 
Além desses conceitos, utilizamos outros procedimentos de forma mais pontual e, por isso, acreditamos que a referência a eles no decorrer das análises será mais produtiva para a organização desse artigo, até pelo caráter de reciprocidade entre a exposição dos conceitos teóricos e a análise que servirá de exemplificação para eles. Assim, para finalizarmos esta seção, fazemos apenas a seguinte alusão.

As análises que empreendemos a seguir também se baseiam em componentes e efeitos da encenação descritiva, procedimentos abordados nos diferentes efeitos de saber, de realidade/ficção, de confidência e de gênero (CHARADEAU, 2012, p. 139-150), e em componentes da encenação narrativa, procedimentos abordados nas maneiras de implicar o destinatário-leitor, nos modos de intervenção do narrador, estatutos e pontos de vista do narrador (CHARAUDEAU, 2012, p. 183-200).

\section{Análise do corpus}

Nesta seção, vamos analisar os três textos que formam o corpus desse trabalho. Em termos metodológicos, salientamos que seguiremos a linha de análise que já incorporamos em outros trabalhos ao investigarmos canções-poemas, por julgarmos ser, até então, a mais produtiva para expor as mudanças no processo de significação decorrente da técnica de hibridização utilizada pela cantora/intérprete Maria Bethânia. Desse modo, dividimos esta seção da seguinte forma: em 3.1, analisamos o trecho mobilizado por Bethânia do livro $O$ rio do meio, de forma independente e conforme sua inserção na obra. Posteriormente, em 3.2, apresentamos a análise da canção "Pra rua me levar"; e, por fim, nos dedicamos à análise da hibridização desses dois textos para evidenciar a canção polifônica enquanto possível gênero emergente, em 2.3.

\subsection{Análise do trecho da obra $O$ rio do meio, de Lya Luft}

Antes de tudo, vejamos algumas informações básicas sobre a autora da obra a ser analisada. Lya Luft nasceu em 1938 no interior do Rio Grande do Sul. Seu início de carreira foi marcado pela tradução de obras literárias em alemão e inglês para o português. A autora transita entre os gêneros literários poemas, crônicas e romances.

No livro $O$ rio do meio, há relatos que evidenciam a passagem da vida infantil para a vida adulta, mostrando o quanto a personagem (ou as diferentes personagens criança e adulta) é intrigada com a vida e seus mistérios. Embora haja na própria especificação dos dados catalográficos da obra a sua classificação como "memórias", a autora faz uma ressalva. Segundo ela, tratar-se-ia de "ensaios mais leves". Tal fato nos lembra a complexidade da classificação dos gêneros literários. Por isso mesmo, não vamos problematizar aqui essa questão, visto que assumimos a noção de narrativa de vida e defendemos que há traços do gênero memórias no livro, independentemente da sua classificação de forma mais generalizada.

A obra está estruturada em sete capítulos, chamando a atenção o uso frequente do verbo falar para denominar cinco deles. Aliás, certamente não por acaso, tal utilização ocorre do segundo capítulo ao sexto, ou seja, as exceções são o primeiro e o último 
capítulos. Respectivamente os títulos são: "Eu falo de infância e madureza", "Eu falo de mulheres e destinos", "Eu falo de homens e seus sonhos", "Eu falo da vida e suas mortes" e "Eu falo de ficções como realidade" (LUFT, 1996).

O trecho que analisamos faz parte do sexto capítulo, "Eu falo de ficções como realidade" (LUFT, 1996, p. 127-145). Mais especificamente, ele foi retirado do início da seção denominada "Notas para um caderno inexistente". Transcrevemos abaixo o trecho que será analisado. Ressaltamos que não o reproduziremos ipsis litteris como Bethânia o citou, mas com alguns trechos a mais, uma vez que, nesta subseção, o nosso objetivo é analisá-lo dentro do contexto da própria obra a que pertence. Assim, poderemos ver, posteriormente, as mudanças de significados decorrentes também da supressão das partes que incluímos agora.

\section{NOTAS PARA UM CADERNO INEXISTENTE}

Quem é essa, agora, que dentro de mim me assusta e me atrai? Sorrateira, ela sou eu ou é alguma sombra que me segue como um bicho rastejando nos calcanhares de minha alma? Lá está, lá está, e sabe tudo, faz tudo: eu sou apenas ferramenta, garganta pela qual ela chama, chama, chama. A quem deseja, quem busca, quem quer?

O que habita um porão, além do frio úmido e silencioso? [...] A mulher do porão era a ama que me criou com todos os meus irmãos [...].

(LUFT, 1996, p. 139-142)

Iniciemos a análise recordando que "descrever consiste em ver o mundo com 'um olhar parado' que faz existir os seres ao nomeá-los, localizá-los e atribuir-lhes qualidades que os singularizam" (CHARAUDEAU, 2012, p. 111; grifos do autor.). No trecho mobilizado, é possível verificar o seguinte em relação a esses mecanismos discursivos. Com o procedimento de nomear, o leitor depara-se com um "eu" que tenta se definir como um "ser" do sexo feminino ou como uma sombra. A partir dessa tentativa de definição, percebe-se a valoração de princípios metafísicos, já que a narradora busca a sua essência ao se questionar sobre os efeitos contraditórios da vida (assustar e atrair). De forma mais específica, nessa caracterização, sobressai a tentativa de compreensão do "eu" em sentido mais geral e abrangente, ou seja, o "eu" assume um posicionamento ontológico. Assim sendo, a narradora indaga o próprio sentido de sua existência através da oposição entre vida e sombra, humano e animal. O questionamento da narradora é se ela é esse sujeito racional que mobiliza valores de teorização sobre o "ser" ou se ela é apenas um bicho, uma sombra.

No que diz respeito ao procedimento de localizar-situar, esse mesmo "eu" situase em um lá. Nesse sentido, esse distanciamento em relação à localização pode ser interpretado como parte da busca de sua essência. Isso quer dizer que esse "eu" não encontra fatos para compreender a sua existência no local de onde enuncia (que seria o aqui) e necessita visualizar um outro espaço-tempo que responda às suas indagações existencialistas. Por isso, a narradora evoca um lugar onde o "eu" se identifica com um "ela", e possivelmente possa explicar a sua qualificação enquanto um sujeito que se assusta e se atrai. Mais uma vez, sobressai uma visão racional da narradora com a finalidade de compreender a si mesma. Fato relevante é que essa compreensão ocorre por meio da evocação de uma parte inferior da casa. Em consequência, tendo vem vista que, 
em psicanálise, o porão corresponde ao inconsciente, percebe-se que tal prática racional é condizente com valores relacionados com princípios dessa ciência.

Além disso, o fato de esse trecho pertencer a um capítulo de um livro faz com que nos indaguemos sobre a sua função discursiva como componente dessa obra. Desse modo, compreendemos que as estratégias descritivas que expusemos nos parágrafos anteriores compõem esse trecho de $O$ rio do meio, que depende parcialmente do modo de organização do discurso narrativo usado em todo o livro. Podemos dizer, então, que esse trecho se caracteriza, predominantemente, como descrição para contar os fatos que constituem parte do capítulo "Eu falo de ficções como realidade".

Vimos, na seção anterior, que, no modo narrativo, o que é destacado é a descoberta por parte do leitor de um mundo que fora construído de acordo com a sucessão de determinadas ações, que, por sua vez, influenciam outras, transformando-as em um encadeamento progressivo, o qual o leitor deve resgatar para compreender os fatos contados. No caso do trecho analisado, o modo descritivo foi usado para mostrar como a narradora foi criada, mediante a projeção do contador: "a mulher do porão era a ama que me criou com todos os meus irmãos" [...] (LUFT, 1996, p. 142). Assim sendo, no discurso do enunciador de $O$ rio do meio, tem-se a imagem de uma narradora que valoriza essa memória afetiva em que se cristalizou a importância da ama na sua criação.

É importante notar que essa relevância inverte determinados valores advindos sobretudo do senso comum. Sabe-se que "ama de criação" e "porão" refletem valores tidos como inferiores por certas camadas da sociedade. Não obstante, através da voz desse contador, percebe-se que o enunciador da canção valora a influência dessa pessoa e desse lugar na formação do caráter da narradora sob um viés racional que dialoga com os ideais da psicanálise.

Não obstante, é preciso ir além nessa caracterização da narradora. Para isso, vejamos os conceitos de efeitos de ficção e efeitos de realidade que "devem ser tratados em conjunto, tendo em vista que o fenômeno de alternância entre esses dois modos de visão do mundo é que constitui o principal interesse de muitos relatos" (CHARAUDEAU, 2012, p. 140), como é o caso da obra analisada. Aliás, já encontramos um caráter sugestivo em relação a isso no próprio título do capítulo analisado: "Eu falo de ficções como realidade". Portanto, vejamos alguns exemplos do próprio capítulo em que esses procedimentos são destacados.

Em "Eu quis escrever romances desde que me lembro de mim" (LUFT, 1996, p. 130), podemos pôr em evidência o fato de que escrever está relacionado diretamente com a atividade chave de uma escritora, no caso, Lya Luft. Logo, emerge de enunciados como esse a imagem de um narrador-descritor cujo objetivo é mostrar parte do mundo real, o que, aliás, é fator essencial para se denominar ou não determinadas obras como memórias ou autobiografias. Nesse caso, nota-se claramente o efeito de realidade impresso à obra.

Já no trecho "linda, a minha filha [...] traz para me mostrar um cachorrinho que ganhou do namorado, e corre com ele no gramado, mas sei que ela é de mentira" (LUFT, 1996, p. 144), ocorre um deslizamento da pessoa ao personagem. Em suma, o "eu" que emerge em sua autorrepresentação constitui uma ficção, uma nova versão de si mesmo (MACHADO, 2014). Ou seja, não há um vínculo automático entre realidade e ficção. 
Embora "eu" conte fatos relacionados a ele próprio, há uma imagem criada que, em última instância, é uma criação, é ficção. No trecho, o efeito de ficção é gerado pela impossibilidade de a autora ter uma filha, pois ela está narrando fatos da infância. Ressalte-se, no entanto, que no final do trecho, já sobressai novamente o efeito de realidade, pois, se a narradora reconhece uma mentira, é porque ela já não se vê como personagem.

Em suma, os dois trechos demonstram a imbricação de efeito de realidade e efeito de ficção na obra como estratégias discursivas atribuídas ao enunciador de $O$ rio do meio; e podem ser ainda mais elucidados a partir do quadro de situação de comunicação proposto pela Semiolinguística (CHARAUDEAU, 2012, p. 52). Quando podemos associar o enunciador (ser de fala) que se projeta como narradora do livro ao sujeito comunicante (ser social), Lya Luft, temos o efeito de realidade. Quando essa associação não é possível, temos um efeito de ficção, pois, ainda que a narrativa seja em primeira pessoa, a narradora é vista como uma nova versão de si mesma. No trecho acima, ela era vista como mãe.

\subsection{Análise da canção "Pra rua me levar"}

Essa canção é de autoria de Ana Carolina e Totonho Villeroy. A cantora e compositora recebeu um CD de ouro e o Prêmio Multishow 2000 (Revelação). No caso da presente canção, ela foi composta em parceria com Totonho Villeroy, também cantor e compositor brasileiro que já recebeu o Prêmio Sharp de Revelação da Musica Popular Brasileira. Vejamos agora a letra dessa canção para prosseguirmos com a análise.

\section{Pra rua me levar}

Não vou viver, como alguém que só espera um novo amor Há outras coisas no caminho onde eu vou Às vezes ando só, trocando passos com a solidão Momentos que são meus, e que não abro mão Já sei olhar o rio por onde a vida passa Sem me precipitar, e nem perder a hora Escuto no silêncio que há em mim e basta Outro tempo começou pra mim agora

Vou deixar a rua me levar

Ver a cidade se acender

A lua vai banhar esse lugar

Eu vou lembrar você

É mas tenho ainda muita coisa pra arrumar Promessas que me fiz e que ainda não cumpri Palavras me aguardam o tempo exato pra falar Coisas minhas, talvez você nem queira ouvir Já sei olhar o rio por onde a vida passa Sem me precipitar, e nem perder a hora Escuto no silêncio que há em mim e basta Outro tempo começou pra mim agora (CAROLINA, 2004, Faixa 12) 
Em termos dos procedimentos relacionados ao modo de organização descritivo nessa canção, destacaremos o seguinte. Há uma ausência da estratégia de nomear, visto que o "eu" da canção não se define. Embora possamos inferir, por exemplo, que se trata de um sujeito que valoriza as diversas dimensões da vida e se recusa a restringir o significado de viver a unicamente viver de (ou por) amor; fato é que não há uma autodefinição, uma vez que o texto está escrito em primeira pessoa, como ocorreu no trecho do livro de Lya Luft, analisado na subseção precedente. Aliás, com essa ausência, a própria questão do sexo do narrador da canção fica indefinida. Portanto, os valores percebidos na dimensão discursiva projetados na figura do narrador dessa canção podem se relacionar tanto a um indivíduo do sexo masculino quanto do sexo feminino.

Esse sujeito situa-se em um caminho por onde vai que lhe oferece outras possibilidades além do amor. Tal fato evidencia que é esse próprio caminho pelo qual ele anda que vai determinando a vida desse "eu", ao ver no agora o começo de um novo tempo. Valoram-se, pois, fatos do cotidiano como o andar na rua. $\mathrm{O}$ fato de ser algo corriqueiro coloca em evidência uma atitude oposta a um comportamento romântico, no qual se idealiza, por exemplo, o amor. Nesse caso, recordemos que o amor no romantismo era visto principalmente sob o prisma da regeneração, o que se pode identificar na canção com a alusão a "alguém que só espera um novo amor". Ou seja, esse alguém valora o sentido da vida unicamente em relação ao amor. Valor rechaçado pelo enunciador da canção mediante as atitudes do narrador.

Além disso, passando para o procedimento de qualificar, percebemos as seguintes qualidades atribuídas a ele: trata-se de um "eu" determinado, solitário (às vezes) e que compreende a vida. Tais aspectos qualificativos permitem a visualização de um sujeito racional. A racionalidade é, portanto, um valor atribuído ao enunciador da canção em oposição ao valor emoção, sobretudo quando este é visto exclusivamente pelo prisma amoroso, como ocorre com o alguém a que o "eu" da canção se refere no primeiro verso do texto. Não obstante, os valores da razão que se destacam aqui estão mais próximos de princípios do realismo do que da psicanálise (caso da obra de Lya Luft). Isso porque o narrador da canção encara os fatos da vida de forma cautelosa, mostrando-se possuir o domínio de sua vida.

Essas estratégias descritivas estão relacionadas ao modo de organização narrativo, pois, ainda que esse modo não seja provavelmente o predominante no gênero textual canção, em sentido mais abrangente, é ele, juntamente com o descritivo, que sobressai em "Pra rua me levar". Tanto que a estratégia de cronologia contínua em progressão, definida como "as ações e as sequências narrativas que estão sob a dependência de um mesmo actante (e) desenrolam-se de maneira progressiva, em seu encadeamento de causa e consequência, sem que seja interrompidas" (CHARAUDEAU, 2012, p. 183, grifos do autor.), pode ser visualizada na canção da seguinte forma. O narrador não vai viver como alguém que só espera um novo amor, visto que: a) há outras coisas em seu caminho; b) ele já sabe olhar o rio por onde a vida passa; c) esse sujeito vai deixar a rua levá-lo; d) outro tempo começou para ele agora.

Por fim, ressaltamos o seguinte. Não podemos dizer que a canção "Pra rua me levar" constitui-se como uma autobiografia, ou, para usarmos o posicionamento teórico que assumimos, como uma (auto)narrativa de vida, pois não há nenhum indício da imbricação entre efeitos de real e efeitos de ficção, por exemplo, como havia em $O$ rio do 
meio e justificava, em termos teórico-metodológicos, tal classificação. No entanto, há uma narrativa de vida (macro ato de linguagem) cuja procedência mais evidente, em termos de análise textual-discursiva, é ficcional: "Quem conta (uma história) não é quem escreve nem quem é (na vida)" (CHARAUDEAU, 2012, p. 183). Ou seja, o narrador da canção (espaço interno) não deve ser confundido com o compositor, letrista ou intérprete (espaço externo), a não ser que haja evidências linguístico-discursivas que possam justificar a sincronização dos dois sujeitos, como ocorreu no trecho de $O$ rio do meio.

\subsection{Análise da canção polifônica "Quem é essa agora/Pra rua me levar"}

Esta hibridização que apresentaremos a seguir faz parte do CD (também lançado em DVD) "Maricotinha ao vivo". Nele encontramos várias hibridizações, algumas das quais (ANDRADE, 2015; 2011) já foram analisadas em outros momentos com objetivos distintos dos apresentados aqui, mas sempre focando o eixo dessa forma peculiar de organização discursiva gerar novos efeitos de sentidos e, por conseguinte, trazer à tona a hipótese de tomarmos esse procedimento como traço condutor de um possível novo gênero discursivo, o qual estamos denominando canção polifônica de Maria Bethânia.

Vejamos agora a reprodução dessa hibridização, com o trecho ipsis litteris mobilizado pela cantora/intérprete, seguido imediatamente da letra da canção.

\section{Texto: Quem é essa agora / Pra rua me levar}

Quem é essa agora?

Que dentro de mim

Me assusta e me atrai

Sorrateira ela sou eu

Ou é alguma sombra

Que me segue como bicho

Rastejando nos calcanhares

da minha alma

Lá está, lá está

Sabe tudo, faz tudo

Eu sou apenas ferramenta

Garganta pela qual

Ela chama, chama, chama...

Não vou viver, como alguém que só espera um novo amor

Há outras coisas no caminho onde eu vou

Às vezes ando só, trocando passos com a solidão

Momentos que são meus, e que não abro mão

Já sei olhar o rio por onde a vida passa

Sem me precipitar, e nem perder a hora

Escuto no silêncio que há em mim e basta

Outro tempo começou pra mim agora

Vou deixar a rua me levar

Ver a cidade se acender

A lua vai banhar esse lugar

Eu vou lembrar você 


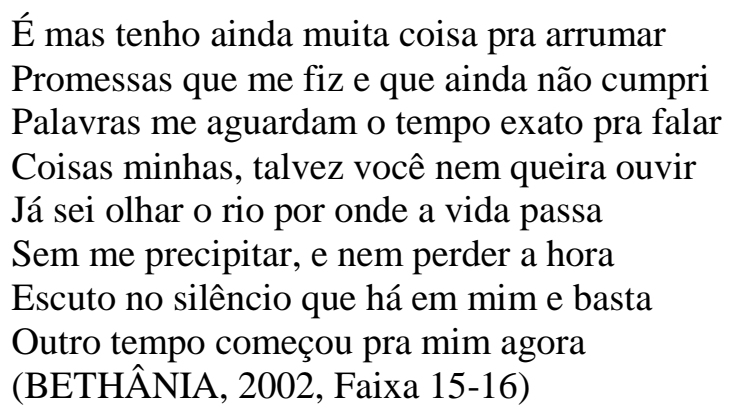

Iniciemos a análise pelos procedimentos do modo de organização descritivo. Dessa forma, é preciso levar em conta, em primeiro lugar, que o processo de nomear, localizar e qualificar acontece em relação a um mesmo sujeito. Quando o "eu" do trecho mobilizado pela cantora/intérprete tenta se definir como um "ela", tal definição se estenderá ao "eu" da canção, visto que há uma sincretização, colocando em evidência o "eu” da canção polifônica.

Nesse caso, faz-se necessário abordar a questão de gênero, pois, na canção analisada de forma independente, vimos que não havia nenhuma evidência linguísticodiscursiva de que o narrador seria homem ou mulher. Já na canção polifônica, trata-se, necessariamente, de um sujeito feminino, mais especificamente de um "eu" feminino que une toda complexidade metafísica presente no trecho do livro de Lya Luft imbricada ao "eu" da canção, resgatado sobretudo pela desinência verbal: "Quem é essa agora?/ Sorrateira ela sou eu/ eu sou apenas ferramenta/ garganta pela qual ela chama, chama, chama/ [Eu] Não vou viver, já sei, vou deixar, tenho, eu vou lembrar, escuto". Desse modo, esse "eu" da canção polifônica possui características da mulher do porão, da narradora do livro cujo posicionamento ora possui traços reais, ora traços ficcionais, e do(a) narrador(a) da canção, que é determinante, que compreende a vida e que, às vezes, é solitário(a), mas que é, sobretudo, realista.

Além disso, percebemos que a hibridização evidencia um processo de ressignificação de alguns procedimentos de qualificar. Recordemos que, na análise do trecho de $O$ rio do meio, mostramos o efeito de realidade resgatado de enunciados como "eu quis escrever romances desde que me lembro de mim" (LUFT, 1996, p. 130), em que a imagem do narrador-descritor é caracterizada como a de uma escritora, mais precisamente da própria Lya Luft. Assim sendo, a qualidade de solitário observada em trechos, como "que me segue como bicho/ rastejando nos calcanhares/ da minha alma", "às vezes ando só, trocando passos com a solidão/ momentos que são meus, e que não abro mão [...] escuto no silêncio que há em mim e basta", surge como uma etapa necessária para escrita. Logo, evidencia-se que escrever é um ato solitário e que tal qualidade é um atributo do(a) escritor(a).

O "eu" da canção polifônica pode ser caracterizado, portanto, como um sujeito escritor. Se a ressignificação da qualidade de solidão já demonstra isso, tal característica é ainda marcada, de forma surpreendente e como linha discursiva dessa agulha (re)construtora de textos/discursos, pela ressignificação de "falar" em "palavras me aguardam o tempo exato pra falar". Nesse enunciado, produzido dentro dessa nova organização discursiva, produto do processo de hibridização realizado por Maria Bethânia, pode-se compreender "falar" como "escrever", servindo inclusive como uma retomada de capítulos do livro: "Eu falo de infância e madureza"; "Eu falo de mulheres 
e destinos"; "Eu falo de homens e sonhos"; "Eu falo da vida e suas mortes"; "Eu falo de ficções como realidade".

Tal fato, aliás, permite uma relação que julgamos procedente com o romance polifônico de Dostoievski. Isso porque nele "alguns títulos de capítulos foram tomados diretamente das palavras do herói; outros foram dados no estilo do herói (BAKHTIN, 2010, p. 291). No caso da canção polifônica que estamos analisando, o "eu" faz referência ao estilo de nomear os capítulos em $O$ rio do meio, que poderia ser visto como uma obra inacabada. Nela, a narradora se dispõe a dar continuidade à obra com um novo capítulo inaugurado como o capítulo dessa canção polifônica, cuja denominação poderia ser algo como "Eu falo de saber olhar o rio por onde a vida passa". Nome que poderia ser imaginado pelo destinatário do enunciador da canção polifônica, já que este tenta convencer aquele a ler essa hibridização por suas entrelinhas, que instauram esse posicionamento e essas ressignificações no discurso da canção polifônica.

Também é necessário ver alguns procedimentos da encenação descritiva de maneira mais detalhada. Vimos, na subseção anterior, que, na canção "Pra rua me levar", não havia efeito de realidade. Agora, a canção enquanto parte da canção polifônica passa a ter esse efeito, já que, com a citação do livro de Lya Luft, o "eu" desse novo texto pode (ou deve) continuar a ser visto como um autor de autobiografia. Não obstante, trata-se de um sujeito que renova suas perspectivas, incluindo mais um tema na sua (auto)narrativa de vida, ainda a ser escrita: "palavras me aguardam o tempo exato pra falar".

Além disso, a expressão "já sei olhar o rio por onde a vida passa" lembra-nos o título do livro, $O$ rio do meio, indicando que o "eu" já sabe ver o passado, o que é uma ação necessária para iniciar uma nova (auto)narrativa de vida. Essa possibilidade de leitura, aliás, é reforçada pelos aspectos simbólicos atribuído ao rio. Um deles é simbolizar a existência humana em seu curso com a sucessão dos desejos, sentimentos, intenções e possibilidades de desvios. Nesse sentido, a narradora da canção polifônica espelha-se no rio, evidenciando a aprendizagem de ressignificar o seu destino, vendo o seu passado apenas como um dos percursos de sua vida, mas que merece ser escrito.

Passemos agora para a análise do modo de organização narrativo. Para tanto, recorremos a este excerto sobre a organização da lógica narrativa que será de grande valia para compreendermos e defendermos a emergência de um novo texto e de um possível novo gênero de discurso. Trata-se do que se denomina em Semiolinguística de princípio de coerência:

a sucessão das ações não é arbitrária, mas, para poder determinar-lhe a coerência, é necessário que ela seja delimitada em seu princípio e seu fim. É preciso, nessa sucessão de ações, que algumas desempenhem um papel narrativo de abertura e outras de fechamento. (CHARAUDEAU, 2012, p. 166; grifos do autor)

Acreditamos então que o trecho de $O$ rio do meio, quando mobilizado pela cantora/intérprete Maria Bethânia, passa a desempenhar a função de papel narrativo de abertura na canção polifônica. Assim, se levarmos em conta apenas a canção, esse papel não é mais desempenhado pelos seus primeiros versos. Com isso, o enunciador da canção polifônica cria uma imagem (éthos) de criador de discursos coerentes, a partir da estratégia de hibridização de textos, que deve ser reconhecida (aceita ou compreendida) 
pelo seu sujeito destinatário. Ressaltamos que essa estratégia discursiva encontra respaldo no procedimento similar que ocorreu com as canções-poemas (ANDRADE, 2015).

Além do mais, é preciso levar em conta que os acontecimentos resgatados do trecho "Quem é essa agora" e da canção "Pra rua me levar" são unificados por dois "eus", fato já evidenciado na análise do modo de organização descritivo, mas que precisamos retomar sob a ótica do modo de organização narrativo. Notamos que o trecho citado por Maria Bethânia é justamente uma parte em que sobressai apenas o modo de organização descritivo. Isso é particularmente interessante, porque, em uma obra em que a (auto)narrativa de vida é o procedimento discursivo preponderante, a parte mobilizada pela cantora/intérprete resgata justamente aquela cujo modo de discurso predominante é o descritivo, ressaltando a finalidade de descrever para contar.

Assim, ao invés de dois protagonistas distintos, temos, na canção polifônica, um actante apenas, o contador enquanto projeção do narrador desse terceiro texto, que passa a (re)contar a sua vida: ele vivia de uma determinada forma, mas decidiu viver com novas perspectivas. Sua nova vida é tema de uma (auto)narrativa de vida que merece ser igualmente relatada - já sei olhar o rio por onde a vida passa/ palavras me aguardam o tempo exato para falar. Nesse caso, há um novo contexto instaurado pela instância enunciativa da canção polifônica, seguindo este procedimento: "para que uma sequência de acontecimentos contados se transforme em narrativa, é preciso inventar-lhe um contexto" (CHARAUDEAU, 2012, p. 153).

Podemos ver, então, que a junção dos dois textos permite uma releitura dentro de um novo contexto instaurado pelo enunciador da canção polifônica para convencer o destinatário a buscar sentidos outros como estes que já evidenciamos até aqui e mais alguns que continuaremos mostrando.

Nessa releitura, precisamos ressaltar alguns aspectos. Da análise de "palavras me aguardam o tempo exato pra falar/ coisas minhas, talvez você nem queira ouvir", depreende-se que a narradora enquanto projeção do sujeito enunciador da canção polifônica valoriza o reconhecimento de ter algo para falar de sua própria vida. Com isso, ela mostra que a elaboração de um relato de vida (como o protagonista imagina dever fazê-la) não é algo simples. Por isso é que a narradora da canção polifônica executará essa tarefa de escritora, apenas depois de cumprir muitas outras. Entretanto, a (auto)narrativa de vida (que já se iniciou com a canção polifônica, conforme sugerimos ao vê-la como um novo capítulo de uma obra aberta) é uma promessa feita pela protagonista: "palavras me aguardam o tempo exato pra falar".

Sobressai também, nesse terceiro texto, a valorização do gênero autobiografia ou outros gêneros em que se privilegia a (auto)narrativa de vida enquanto macro ato de linguagem. Quando a narradora afirma que as palavras estão aguardando o tempo mais propício para serem escritas por ela, independentemente da disponibilidade do destinatário para ouvi-las, há uma valorização dessa prática discursiva, muitas vezes vista, principalmente em textos embasados em posicionamentos do senso comum, como um procedimento muito simples e até mesmo sem muito valor estético. Tanto que, às vezes, ela é descrita apenas como um texto que tem de ser escrito em primeira pessoa. Ideia que a canção polifônica ajuda a contrapor, ao evidenciar que o "eu" dessa hibridização reúne 
em si um conjunto de vozes que acreditamos ser compatível com o conceito de polifonia, conforme demonstra o trecho seguinte.

Compreende-se perfeitamente que no centro do mundo artístico de Dostoievski deve estar situado o diálogo, e o diálogo não como meio, mas como fim. Aqui o diálogo não é o limiar da ação, mas a própria ação. Tampouco é um meio de revelação, de descobrimento do caráter como que já acabado do homem. Não, aqui o homem não apenas se revela exteriormente como se torna, pela primeira vez, aquilo que é, repetimos, não só para os outros, mas também para si mesmo. Ser significa comunicar-se pelo diálogo. Quando termina o diálogo, tudo termina [...] Nos romances de Dostoievski, tudo se reduz ao diálogo, à contraposição dialógica como centro. Tudo é meio, o diálogo é o fim. Uma só voz nada termina e nada resolve. Duas vozes são o mínimo de vida, o mínimo de existência. (BAKHTIN, 2010, p. 293)

Para nós, na canção polifônica, também tudo se reduz ao diálogo. O posicionamento do enunciador instaurado nesse terceiro texto é o reflexo de um conjunto de vozes: há a voz, no plano externo, da escritora Lya Luft e da cantora/Intérprete Maria Bethânia, juntamente com os compositores da canção "Pra rua me levar", Ana Carolina e Totonho Villeroy. No plano interno, há a voz dos(as) narradores(as) e personagens do livro $O$ rio do meio e do narrador da canção que nada terminam, ao contrário, são unidas na voz do enunciador da canção polifônica que se significa através do diálogo agora estabelecido com seu destinatário. Este deve reconhecer ou não essa estratégia argumentativa inscrita em seu discurso, resgatando os valores atribuídos não ao enunciador da canção ou ao enunciador da autobiografia, mas sim ao enunciador da canção polifônica.

Por fim, chamamos a atenção para o fato de essa forma de composição da canção polifônica ter, inclusive, a estabilização de um efeito de gênero. "Esse efeito resulta de alguns procedimentos de discurso que são suficientemente repetitivos e característicos de um gênero para tornar-se o signo deste" (CHARAUDEAU, 2012, p. 142). Um exemplo dado pelo próprio autor é o uso de "era uma vez", que produz o efeito de um conto maravilhoso.

Ora, não é isso o que ocorre exatamente com a canção polifônica? A citação feita pela intérprete seria justamente a primeira fase de uma canção polifônica, o que gera a expectativa no leitor (ouvinte) de indagar-se qual será a canção hibridizada e quais serão as conexões possíveis em outras ocasiões, incluindo aquelas por nós apontadas nos quadros da primeira seção deste artigo. Ressaltamos que, apesar de havermos utilizado nomenclaturas diferentes em trabalhos anteriores devido ao quadro teórico-metodológico escolhido, esse princípio já encontrava justificativa na defesa de que a canção-poema possui uma organização textual particular ( $c f$. ANDRADE, 2015).

Tal fato reforça a nossa hipótese de que a hibridização realizada por Maria Bethânia pode ser caracterizada como um gênero de discurso emergente, denominado inicialmente de canção-poema, mas que agora, através da análise apresentada, acreditamos ser mais viável denominá-la de canção polifônica de Maria Bethânia. Assim, o termo pode abarcar as hibridizações anteriores entre canções e poemas ( $c f$. ANDRADE, 2015), a presente hibridização entre canção e trecho de um livro de memória e outras 
hibridizações, conforme ilustramos nos quadros 2 e 3 da seção 1 , mostrando inclusive a diversidade dos gêneros literários mobilizados pela cantora/intérprete ao longo de sua carreira.

Podemos definir, então, a canção polifônica de Maria Bethânia da seguinte forma. Esse gênero de discurso se constitui a partir de um processo de hibridização entre a canção e outros gêneros literários: poema, peça de teatro (dramaturgia), conto, romance, memórias e novela. Dessa articulação, surgem novos efeitos de sentido a partir da formação de um terceiro texto cujo contrato é regido pelo enunciador da canção polifônica. A justificativa dessa terminologia vem da referência que fizemos ao conceito de polifonia de Bakhtin. O surgimento da voz do enunciador da canção polifônica está ancorado na relação dialógica entre a canção e outros gêneros literários; e é a partir da sua voz que o seu destinatário poderá resgatar os valores inscritos em seu discurso. Valores enquanto processos de significação que não se confundem com aqueles inscritos dentro do quadro enunciativo de cada texto tomado separadamente, conforme demonstramos no seguinte quadro, retomando as análises realizadas neste artigo.

Quadro 4. Síntese da hibridização entre a canção Pra rua me levar e o trecho da autobiografia 0 rio do meio.

\begin{tabular}{|c|c|c|c|}
\hline $\begin{array}{c}\text { Canção } \\
\text { polifônica }\end{array}$ & $\begin{array}{c}\text { Enunciador do } \\
\text { trecho de } O \text { rio do } \\
\text { meio }\end{array}$ & Enunciador da canção & $\begin{array}{c}\text { Enunciador da canção } \\
\text { polifônica }\end{array}$ \\
\hline $\begin{array}{l}\text { Quem é essa } \\
\text { agora / Pra } \\
\text { rua me levar }\end{array}$ & $\begin{array}{l}\text { Valoração } \\
\text { princípios metafísicos } \\
\text { na constituição de um } \\
\text { "eu" feminino; } \\
\text { posicionamento } \\
\text { ontológico; visão } \\
\text { racional condizente } \\
\text { com a psicanálise; } \\
\text { reconhecimento do } \\
\text { papel da ama de } \\
\text { criação em sua } \\
\text { formação; efeito de } \\
\text { realidade e ficção. }\end{array}$ & $\begin{array}{l}\text { Não há delimitação do sexo } \\
\text { do narrador; valoração de } \\
\text { fatos cotidianos; oposição } \\
\text { aoramto } \\
\text { romântico; compreensão da } \\
\text { vida de forma cautelosa } \\
\text { segundo princípios } \\
\text { realistas; efeito de ficção. }\end{array}$ & $\begin{array}{l}\text { O narrador é um sujeito } \\
\text { feminino com posicionamento } \\
\text { metafísico e realista; a narradora } \\
\text { é escritora; falar significa } \\
\text { escrever e a escrita é } \\
\text { ressignificada enquanto ato } \\
\text { solitário; sobressai o estilo de } \\
\text { nomear capítulos de livro em } \\
\text { conformidade com o estilo } \\
\text { adotado em } O \text { rio do meio; } \\
\text { valoração do gernero } \\
\text { autobiografia; todos esses } \\
\text { significados podem } \\
\text { visualizados apenas na/pela voz } \\
\text { do enunciador da canção } \\
\text { polifônica enquanto resultado de } \\
\text { combinação, contraposição, } \\
\text { separação de outras vozes que } \\
\text { gera um terceiro texto. }\end{array}$ \\
\hline
\end{tabular}

\section{Conclusão}

As análises demonstram que a organização do discurso da canção polifônica é um princípio peculiar desse gênero emergente, não presente nos textos tomados isoladamente. Vimos, assim, que, na organização do discurso da canção polifônica, há um destinatário diferente do destinatário do livro $O$ rio do meio e da canção "Pra rua me levar", já que, do discurso do enunciador da canção polifônica, emergiu uma imagem de um "narrador" peculiar cujas novas características e representações devem ser reconhecidas pelo destinatário desse possível novo gênero de discurso. 
Em suma, algumas dessas novas representações foram ilustradas pela questão de gênero instaurada na canção polifônica, cujo narrador deve ser visto como uma narradora que possui características da narradora de $O$ rio do meio, a partir de efeitos de realidade e de ficção, de personagens desse livro, como a mulher do porão, além de ser determinante compreender a vida, ser solitária e realista. Também vimos mudanças significativas instauradas no discurso desse enunciador das representações de solidão e de rio, por exemplo, que passaram a ter um significado dentro da prática de escrever, visto que a narradora da canção polifônica possui traços de uma escritora.

Acreditamos ter evidenciado que a imagem do enunciador da canção polifônica é, em linhas gerais, a de um criador de textos coerentes cuja composição emerge de estratégias descritivas e narrativas. Além do mais, tais estratégias se resumem, em termos mais gerais, a um efeito de gênero, pois o fato de a cantora/intérprete mobilizar poemas (em parte ou no todo) ou trechos de textos de outros gêneros literários em diferentes CDs, como apontamos na primeira seção, possibilita-nos ver a hibridização enquanto um procedimento de discurso que tem sido suficientemente repetitivo e característico de um gênero para tornar-se seu próprio signo.

Gênero que aqui denominamos canção polifônica para abarcar as hibridizações entre canções e poemas analisadas em trabalhos anteriores, entre a canção e trechos de outros gêneros literários. A hibridização entre a canção e o trecho de $O$ rio do meio serviunos, neste artigo, de exemplo, e também para fazermos referência ao romance polifônico: termo que sustentou a tese de um novo gênero de discurso e que também parece sustentar a possível emergência do gênero canção polifônica de Maria Bethânia.

Portanto, as hibridizações realizadas por Maria Bethânia ao longo de sua trajetória artística podem ser vistas como um gênero de discurso emergente, a canção polifônica. Já havíamos lançado essa hipótese com a análise de sete canções-poemas (ANDRADE, 2015), trazendo um exemplo concreto de uma delas na seção 1. Neste artigo, apresentamos uma análise de outro gênero literário (a autobiografia) e elaboramos dois quadros com oito hibridizações, lançando a hipótese de que esse procedimento de hibridização possui um respaldo teórico-metodológico tanto em trabalhos anteriores, como neste, incluindo a diversidade de teorias mobilizadas.

Passamos a denominar essas hibridizações de canção polifônica porque o termo canção-poema era utilizado para colocar em evidência a mobilização do gênero poema hibridizado com a canção. Já com o termo canção polifônica conseguimos mostrar as características desse gênero a partir da mobilização de diferentes gêneros literários. Ela é polifônica porque dessa hibridização surge a voz de um enunciador responsável pelo estabelecimento de um novo contrato com significados outros, que são diferentes daqueles inscritos no discurso do enunciador de cada texto mobilizado pela cantora/intérprete Maria Bethânia (canção, poema, autobiografia etc.).

Esse enunciador da canção polifônica também é a fonte para se compreender a reorganização desse novo discurso, uma vez que os trechos de obras literárias (incluindo os poemas que analisamos em trabalhos anteriores), quando citados antes da canção interpretada, passam a exercer o papel de abertura narrativa de um terceiro texto. Se já havíamos lançado a hipótese dessa hibridização poder ser um "novo" gênero de discurso (a canção-poema) com base nos conceitos de estilo, construção composicional e conteúdo 
temático em Andrade (2015), por meio da noção de efeito de gênero, vimos essa hipótese ser reforçada por a canção polifônica ter inclusive a estabilização de um efeito de gênero, uma vez que esse procedimento é suficientemente repetitivo e característico da canção polifônica de Maria Bethânia.

\section{Referências bibliográficas}

ANDRADE, R.B. Semiótica, éthos e gêneros de discurso nas canções-poemas de Maria Bethânia. Curitiba: CRV, 2015.

Polifonia e fluxo informacional: Bethânia reorganiza o discurso. DIÁLOGO DAS LETRAS, Pau dos Ferros, v. 1, n.1, p. 135-145, jan./jun.2012.

Apesar de você (quem?): a produção de sentidos orientada por Maria Bethânia. XI SEMINÁRIO INTERNACIONAL EM LETRAS: LINGUAGENS E PRÁTICAS SOCIOCULTURAIS, Anais.... Santa Maria: 2011, p. 1-9.

BAKHTIN, M. Problemas da poética de Dostoievski. Rio de Janeiro: Forense Universitária, 2010.

Estética da criação verbal. 4. ed. São Paulo: Martins Fontes, 2003.

BETHÂNIA, M. [Texto] Quem é essa agora/Pra rua me levar. Intérprete Maria Bethânia. Maricotinha ao vivo. São Paulo: Biscoito Fino, 2002. Faixas 22-23.

CAROLINA, A. Pra rua me levar. Intérprete Ana Carolina. DVD Estampado. São Paulo: BMG, 2004. Faixa 12.

CHARAUDEAU, P. Linguagem e discurso: modos de organização. [Org. de Aparecida Lino Pauliukonis e Ida Lúcia Machado]. São Paulo: Contexto, 2012.

Grammaire du sens et de I’expression. Paris: Hachette, 1992.

CRUZ, D.F. da. O éthos dos romances de Machado de Assis. São Paulo: Nankin; EdUSP, 2009.

DOURADO, H.A. Dicionário de termos e expressões da música. São Paulo: Ed. 34, 2004.

FIORIN, J.L. Em busca dos sentidos: estudos discursivos. São Paulo: Contexto, 2008.

GREIMAS, A.J.; COURTÉS, J. Dicionário de semiótica. 2a . ed. São Paulo: Contexto, 2011.

HOUAISS, A.; VILLAR, M. de S. Dicionário Houaiss da língua portuguesa. Rio de Janeiro: Objetiva, 2009. 
KENNEDY, M. Dicionário Oxford de música. Trad. Bras. Lisboa: Dom Quixote, 1994. LARA, G.M.P.; ANDRADE, R.B. Uma releitura de 'O navio negreiro' e 'Um índio': a reconstrução textual e a possibilidade de um 'novo gênero'. Cadernos do IL, Porto Alegre, v. 1, n. 46, p. 171-191, jun. 2013. Disponível em $<$ http://seer.ufrgs.br/index.php/cadernosdoil/article/view/35968/25736>; acesso em ago. 2016.

LUFT, Lya. O rio do meio. São Paulo: Mandarim, 1996.

MACHADO, I.L. Narrativa de vida e construção de identidade. EM: LARA, G.P.; LIMBERTI, R.P. (Orgs.) Discurso e (des)igualdade social. São Paulo: Contexto, 2015.

Algumas imbricações entre narrativa de vida e Semiolinguística. CONGRESSO INTERNACIONAL DE ESTUDOS DO DISCURSO. São Paulo. Resumos dos trabalhos apresentados. Disponível em $\langle$ http://cied.fflch.usp.br/node/15 $>$; acesso em ago. 2014.

As palavras de uma análise do discurso. Em: LARA, G.M.P.; MACHADO, I.L.; EMEDIATO, W. (Orgs.). Análises do discurso hoje. v. 2. Rio de Janeiro: Nova Fronteira, 2008.

MAIGUENEAU, D. Doze conceitos em Análise do discurso. [Org. de Sírio Possenti e Maria Cecília P. de Souza-e-Silva]. São Paulo: Parábola, 2010.

A propósito do éthos. Em: MOTTA, A.R.; SALGADO, L. (Orgs.). Ethos discursivo. São Paulo: Contexto: 2008. p. 11-29.

MARCUSCHI, L.A. Produção textual, análise de gêneros e compreensão. São Paulo: Parábola, 2008.

SABINO, P. A rainha da voz. Revista união brasileira de compositores. Rio de Janeiro, n. 4, p. 19, jan. 2010.

Artigo recebido em: abril de 2016.

Aprovado e revisado em: junho de 2016.

Publicado em: agosto de 2016

\section{Para citar este texto:}

ANDRADE, Rafael Batista. A (auto)narrativa de vida na construção da canção polifônica Quem é essa agora/Pra rua me levar de Maria Bethânia. Entremeios [Revista de Estudos do Discurso], Seção Estudos, Programa de Pós-graduação em Ciências da Linguagem (PPGCL), Universidade do Vale do Sapucaí, Pouso Alegre (MG), vol. 13, p. 87-109, jul. - dez. 2016.

DOI: http://dx.doi.org/10.20337/ISSN2179-3514revistaENTREMEIOSvol13pagina87a109 